\title{
CLIMACTERIC: INTENSITY OF SYMPTOMS AND SEXUAL PERFORMANCE ${ }^{1}$
}

\author{
Estela Rodrigues Paiva Alves², Aurélio Molina da Costa3, Simone Maria Muniz da Silva Bezerra4, Ana \\ Marcia Spano Nakano ${ }^{5}$, Ana Márcia Tenório de Souza Cavalcanti ${ }^{6}$, Maria Djair Dias ${ }^{7}$
}

\footnotetext{
${ }^{1}$ Excerpt from the dissertation - O padrão de desempenho sexual e a intensidade da síndrome do climatério em um grupo de mulheres que realizam atividade física, submitted to the Nursing Graduate Associate Program (PPGEnf) of the Universidade de Pernambuco (UPE) and the Universidade Estadual da Paraíba (UEPB) in 2012.

2 Doctoral student of PPGEnf/UFPB. João Pessoa, Paraíba, Brazil E-mail: rodrigues.estela@gmail.com

${ }^{3}$ Physician. Ph.D. in Family Planning. Professor of the Faculty of Life Sciences of UPE and of PPGEnf/UPE/UEPB. Recife, Pernambuco, Brazil. E-mail: aumolina55@gmail.com

${ }^{4}$ Post-doctorate at the Ribeirão Preto College of Nursing. Professor of the PPGEnf/UPE/UEPB. Recife, Pernambuco, Brazil. E-mail: simonemunizm2@gmail.com

${ }^{5}$ Ph.D. in Nursing. Professor of the Public Health Nursing Graduate Program. Ribeirão Preto, São Paulo, Brazil. E-mail: nakano@ eerp.usp.br

${ }^{6}$ Nurse. Professor of the PPGEnf/UFPE Recife, Pernambuco, Brazil. E-mail: anapopita@gmail.com

${ }^{7}$ Ph.D. in Nursing. Professor of the PPGEnf/UFPB João Pessoa, Paraíba, Brazil. E-mail: mariadjair@yahoo.com.br
}

\begin{abstract}
This paper had the aim to checking the association between the intensity of climacteric symptoms and the pattern of sexual performance of women in this period of the life cycle. A transversal study conducted from July to September 2011 involving 260 climateric women of a physical exercise program. The women were evaluated using the Kupperman Menopausal Index and of the Sexual Quotient. For statistical analysis, there were used: average, standard deviation, percentages and Fisher Exact Test. The women with sexual performance standard good/excellent, mostly, reported mild symptoms in Menopausal Index, and those who had a bad pattern/unfavorable, had high percentages of moderate and severe manifestations. Symptoms of mild intensity were associated with a higher standard of sexual performance, showing that changes in this pattern have strong relationship with the intensity of symptoms. DESCRIPTORS: Climacteric. Sexuality. Motor activity. Health promotion. Nursing.
\end{abstract}

\section{CLIMATÉRIO: A INTENSIDADE DOS SINTOMAS E O DESEMPENHO SEXUAL}

RESUMO: O presente estudo objetivou verificar a associação entre a intensidade dos sintomas no climatério e o padrão de desempenho sexual de mulheres neste período do ciclo vital. Estudo transversal, realizado de julho a setembro de 2011, envolvendo 260 mulheres no climatério de um programa de atividade física. As mulheres foram avaliadas por meio do Índice Menopausal de Kupperman e do Quociente Sexual. Para análise estatística utilizou-se: média, desvio-padrão, porcentagens e Teste Exato de Fisher. As mulheres com padrão de desempenho sexual bom/excelente, em sua maioria, referiram apresentar sintomas leves na escala menopausal, e as que apresentaram um padrão ruim/desfavorável, tinham altos percentuais de manifestações moderadas e intensas. Os sintomas de intensidade leve estiveram associados a um melhor padrão de desempenho sexual, presumindo-se que alterações neste padrão tem forte relação com a intensidade dos sintomas.

DESCRITORES: Climatério. Sexualidade. Atividade motora. Promoção da saúde. Enfermagem.

\section{CLIMATERIO: LA GRAVEDAD DE LOS SÍNTOMAS Y EL DESEMPEÑO SEXUAL}

RESUMEN: El presente estudio tuvo como objetivo investigar la asociación entre la intensidad de los síntomas del climaterio y el patrón de la actividad sexual de mujeres durante este período del ciclo vital. Estudio transversal realizado entre julio y septiembre de 2011 con la participación 260 mujeres de un programa de actividad física que se encontraban en el climaterio. Se evaluaron las mujeres con el índice menopáusico Kupperman y Cociente Sexual. Para el análisis estadístico se utilizó: el promedio, la desviación estándar, los porcentajes y la Prueba Exacta de Fisher. Las mujeres con estándar de desempeño sexual bueno/excelente, mayoritariamente, reportaron síntomas leves en el índice menopáusico, y las que tenían un patrón malo/desfavorable tuvieron tasas altas de manifestaciones moderadas y graves. Los síntomas de intensidad leve se asociaron con un mejor patrón de rendimiento sexual, demostrando que los cambios en este índice tienen fuerte relación con la intensidad de los síntomas.

DESCRIPTORES: Climaterio. Sexualidad. Actividad motora. Promoción de la salud. Enfermería. 


\section{INTRODUCTION}

The climacteric period is a biological phase of women's life cycle, which usually starts around the age of 40 and can be extended to the age of 65 . It is characterized by the decrease in the production of estrogen and progesterone hormones by the ovaries. ${ }^{1}$

Climacteric is not always associated with common physical and emotional changes that occur during this period, but when they appear, they are called the climacteric syndrome. Climacteric symptoms are influenced by many biological factors (related to the decrease of estrogen levels or as a result of senility), by psychological aspects (which involve women's self-perception, that is, how they face this moment in life) and by social aspects (those related to the interaction of women with relatives, friends and the community). Community has a strong relationship with sociocultural aspects, such as myths, beliefs and prejudices that society creates, disseminates and experiences at every age..$^{1-3}$

Climacteric women who have some of the characteristic symptoms of the syndrome, such as hot flashes, insomnia, irritability, depression, high blood pressure, urgency of urination, as well as those who have no partner and have a bad selfperception of their general state tend to present changes in their sexuality. ${ }^{2}$

The physiological changes that occur with climacteric women, although with symptoms of different intensity, may affect their general wellbeing. ${ }^{4}$ These changes will not necessarily reduce sexual pleasure, but may directly affect sexual response, making it longer and less enjoyable, thus resulting in sexual dissatisfaction. Dyspareunia (painful sexual intercourse) resulting from vaginal dryness, which is in turn due to estrogen deficiency, is one of the main causes for sexual discomfort that may cause changes in women's sexual life. ${ }^{1}$

It is known that care of climacteric women, including their sexuality, is one of the priorities of Public Health Policies ${ }^{5}$ aimed at women, even though some professionals still focus on diagnoses and treatment of clinical complaints, resulting in medication rather than in the assessment of subjective complaints such as sexual dissatisfaction, concern with the lack of sexual desire, sense of guilt for changes in the family environment, in their bodies and in the relationship with their partner. ${ }^{1,6}$

Sexuality appears as an important aspect of quality of life in climacteric, as hormonal changes have an influence on women's libido. In addition, sexuality has historically gathered a lot of myths, taboos and beliefs over time and within different societies, which makes it evident that it requires special attention from health professionals, so as to deliver good quality services to women, with the aim to provide a comprehensive care service. ${ }^{7}$

It is known that women have been increasingly concerned with changes in their bodies, including the pleasant aspect of sex rather than its reproductive function, in order to have a better quality of life, which also means to be free of climacteric symptoms that hamper their general well-being; therefore the need for attention regarding this particular aspect is evident. ${ }^{8}$

Comprehensive care must be provided to climacteric women. However, in practice, these actions have not been developed yet. It is worth mentioning the lack of studies on the topic, which highlights the importance of focusing on matters related to climacteric, as it is necessary to identify problems experienced during this period in order to reduce them. ${ }^{9}$

Therefore, in view of the difficulties experienced by health professionals in approaching climacteric women, regarding sexuality aspects, and due to the lack of information about the topic, we sought to give more visibility to climacteric symptoms and their effects on women's sexual life.

Based on the above considerations, we questioned whether women with more intense symptoms of climacteric had a lower pattern of sexual response, with the objective to assess the association between the intensity of climacteric symptoms and the sexual performance standards of women who were at this stage of the life cycle.

\section{METHOD}

This is a cross-sectional study with 260 climacteric women. The study was conducted at the City Health Club Program of Recife (PAC, as per its acronym in Portuguese), implemented by 
the Health Secretariat of Recife in 2002 as a health promotion policy of the Unified Health System (SUS), which consisted of providing physical and leisure activities, as well as information on healthy eating habits in order to improve the quality of life of the local population. ${ }^{10}$

Over the period of study, the PAC was composed of 21 hubs located in different neighborhoods of Recife, and of six Sanitary Districts (SD): I, II, III, IV, V and VI. We chose to select 10 hubs randomly, due to the absence of a record system of users, which was a limitation of this study in the definition of the sample size. In this sense, the hubs drawn were: Coque, Ilha do Leite and Praça 13 de Maio (DS-I); Ilha do Joaneiro and Praça do Hipódromo (DS-II); Sítio Trindade (DS-III); Engenho do Meio and Praça do Poeta (DS-IV); San Martin (DS-V); and $2^{\circ}$ Jardim de Boa Viagem (DS-VI). All women who attended the drawn hubs between July and September 2011 were questioned, as long as the inclusion criteria were met.

The established inclusion criteria were: being aged between 40 and 65 years old, being in climacteric, ${ }^{1}$ being a PAC user and doing physical exercise at least three times a week for a month, and having had sexual intercourse in the last six months prior to the interview; this last criterion was pre-established by one of the instruments used in this investigation. ${ }^{11}$ Exclusion criteria were applied to: women who made use of oral contraception pills, those who were under a hormone replacement therapy or who were using phytoestrogens, since these substances interfere in the climacteric symptomatology. ${ }^{11-12}$

For data collection, the instruments used were: a semi-structured questionnaire containing socioeconomic and demographic data such as age, race, marital status, education, profession and per capita income; the Blatt-Kupperman menopausal index (BKMI); and the Sexual Quotient - female version (SQ-F). ${ }^{13-14}$

The BKMI is an instrument that has been already validated in Brazil and it is used to specify and classify climacteric symptoms. It includes 11 symptoms/complaints (vasomotor symptoms, paresthesia, melancholy, vertigo, fatigue, arthralgia/myalgia, headache, palpitations and tingling). A score was given for each symptom that ranged from mild (result lower or equal to
19); moderate (between 20 and 25) and intense (over 35); for the latter, a score over 35 suggests menopause, which is characterized by the absence of menstruation for 12 consecutive months. In order to obtain the total score, the scores were added and the higher the score obtained, the more intense the symptoms were. ${ }^{13}$

Standards of sexual performance were classified by means of the Female Sexual Quotient (SQ-F), which is also valid in Brazil. The results of sexual performance standards were obtained using the following formula: $2 x(\mathrm{Q} 1+\mathrm{Q} 2+\mathrm{Q} 3+$ $\mathrm{Q} 4+\mathrm{Q} 5+\mathrm{Q} 6+[5-\mathrm{Q} 7]+\mathrm{Q} 8+\mathrm{Q} 9+\mathrm{Q} 10)$, where $\mathrm{Q}=$ question and [5-Q7] = question number 7 requires this previous subtraction and the result must be included in the equation. Women who obtained scores between 0 and 20 have zero or a poor sexual performance standard; between 22 and 44, poor or insufficient; between 42 and 60, insufficient or fair; between 62 and 80, fair or good; between 82 and 100, good or excellent. ${ }^{15}$

Data were gathered and analyzed with the statistics software SPSS (Statistical Package for the Social Sciences) version 15. For the analysis, descriptive statistics techniques were used (absolute, univariate and bivariate percentage distributions, mean and standard deviation), as well as inferential statistics by means of Fisher's Exact Test. This test was used because the study sample was too small, which did not allow for the use of the Chisquare Test. Significance was set at $5 \%$.

The study was submitted to the appreciation of the Research Ethics Committee of the University of Pernambuco and met the requirements of Resolution 196/96 of the Health Council of Brazil, ${ }^{16}$ being approved under protocol number no. 059/11. Data were only collected after the approval of the project by the Research Ethics Committee and the signing of a Free and Informed Consent Form by the participants.

\section{RESULTS}

The mean age of the interviewees $(n=260)$ was 51 years. The profile of the interviewed women was non-white $(66.2 \%)$, in a stable relationship (82.3\%), Catholic (72.7\%) with eight or more years of schooling. Regarding profession/occupation, $63.5 \%$ had a paid work and the others were housewives, $44.2 \%$ had a monthly per capita income over the minimum wage, as 
shown in table 1.

Table 1 - Distribution of women aged between 40 and 65, according to socioeconomic and demographic data. Recife, Pernambuco, JulySeptember $2011(n=260)$

\begin{tabular}{|c|c|c|}
\hline Variable & $\mathbf{n}$ & $\%$ \\
\hline \multicolumn{3}{|l|}{ Age group } \\
\hline 40 to 49 & 124 & 47.7 \\
\hline 50 to 59 & 91 & 35.0 \\
\hline 60 to 65 & 45 & 17.3 \\
\hline Mean (SD) & 51.0 & 7.22 \\
\hline \multicolumn{3}{|l|}{ Race } \\
\hline White & 88 & 33.8 \\
\hline Non-white & 172 & 66.2 \\
\hline \multicolumn{3}{|l|}{ Marital status } \\
\hline Single (divorced/widowed) & 46 & 17.7 \\
\hline Married (stable relationship) & 214 & 82.3 \\
\hline \multicolumn{3}{|l|}{ Religion } \\
\hline Catholic & 189 & 72.7 \\
\hline Evangelical & 42 & 16.2 \\
\hline Spiritist & 20 & 7.7 \\
\hline Others & 9 & 3.5 \\
\hline \multicolumn{3}{|l|}{ Education (years of study) } \\
\hline Did not attend school & 9 & 3.5 \\
\hline $1-7$ & 99 & 38.1 \\
\hline$\geq 8$ & 152 & 58.5 \\
\hline \multicolumn{3}{|l|}{ Profession } \\
\hline Paid work & 165 & 63.5 \\
\hline Unpaid work & 95 & 36.5 \\
\hline \multicolumn{3}{|c|}{$\begin{array}{l}\text { Per capita income ( } x \text { times the minimum } \\
\text { wage)* }\end{array}$} \\
\hline Up to $1 / 2$ & 97 & 37.3 \\
\hline Between $1 / 2$ and 1 & 46 & 17.7 \\
\hline Over 1 & 115 & 44.2 \\
\hline Not provided/not able to inform & 2 & 0.8 \\
\hline Total & 260 & 100.0 \\
\hline
\end{tabular}

* The values were calculated based on the 2011 minimum wage (540.00 Brazilian reais).

Regarding the intensity of symptoms, $47.7 \%$ of women had mild manifestations and about one sixth reported intense symptoms (Figure 1).

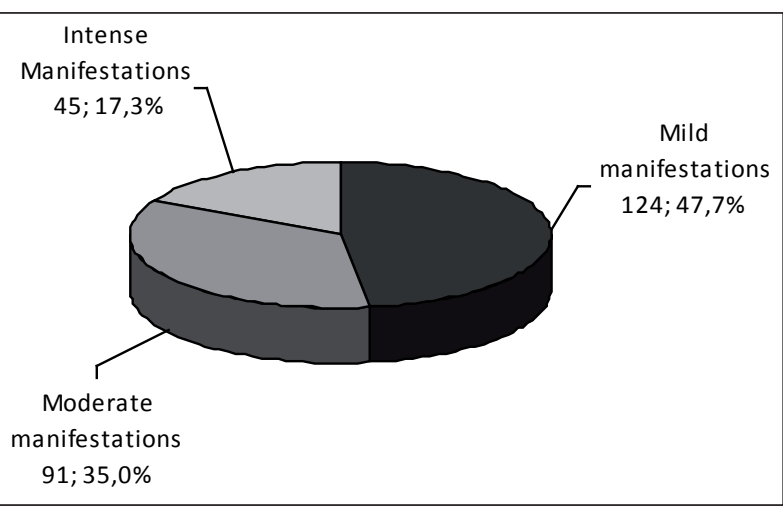

Figure 1 - Distribution of women aged between 40 and 65 , according to the intensity of symptoms, based on the BKMI classification. Recife, Pernambuco, July-September $2011(n=260)$

Table 2 shows that $46.2 \%$ of the women in this study had a standard of sexual performance considered as good, and 3.8\% considered as excellent.

Table 2 - Distribution of women aged between 40 and 65 , according to their standard of sexual performance. City Health Club, Recife, Pernambuco, July-September $2011(n=260)$

\begin{tabular}{lcc}
\hline Variable & $\mathbf{n}$ & $\mathbf{\%}$ \\
\hline Standard of sexual performance & & \\
Poor & 25 & 9.6 \\
Insufficient & 25 & 9.6 \\
Fair & 80 & 30.8 \\
Good & 120 & 46.2 \\
Excellent & 10 & 3.8 \\
\hline Total & $\mathbf{2 6 0}$ & $\mathbf{1 0 0 . 0}$ \\
\hline
\end{tabular}

In order to better interpret the related data, four of the five variables of the SQ-F (poor, insufficient, good, excellent) were merged as poor/ insufficient and good/excellent, respectively.

In table 3 , it is possible to observe that women with good/excellent standards of sexual performance mostly reported mild symptoms of the menopausal scale, and among those who had a poor/insufficient standard, high percentages of moderate or intense symptoms were found. The association between the two scales was significant $(\mathrm{p}<0.001)$. 
Table 3 - Correlation between the standard of sexual performance and the intensity of climacteric symptoms of women aged between 40 and 65 years old. Recife, Pernambuco, July-September 2011 $(n=260)$

\begin{tabular}{|c|c|c|c|c|c|c|c|c|c|}
\hline \multirow{3}{*}{ Standard of sexual performance } & \multicolumn{8}{|c|}{ Blatt \& Kupperman Index } & \multirow{3}{*}{$p$ value } \\
\hline & \multicolumn{2}{|c|}{ Mild } & \multicolumn{2}{|c|}{ Moderate } & \multicolumn{2}{|c|}{ Intense } & \multicolumn{2}{|c|}{ Total } & \\
\hline & $\mathbf{n}$ & $\%$ & $\mathbf{n}$ & $\%$ & $\mathbf{n}$ & $\%$ & $\mathbf{n}$ & $\%$ & \\
\hline Poor/Insufficient & 27 & 54.0 & 13 & 26.0 & 10 & 20.0 & 50 & 100.0 & $\mathrm{p}^{(*)}<0.001 \dagger$ \\
\hline Fair & 61 & 76.3 & 19 & 23.8 & - & - & 80 & 100.0 & \\
\hline Good/excellent & 108 & 83.1 & 20 & 15.4 & 2 & 1.5 & 130 & 100.0 & \\
\hline Total Group & 196 & 75.4 & 52 & 20.0 & 12 & 4.6 & 260 & 100.0 & \\
\hline
\end{tabular}

* Fisher's Exact Test/ † Significant difference at 5.0\%.

\section{DISCUSSION}

The studied women practiced physical exercise at least three times a week for a month, and based on the BKMI, only a minority reported intense symptoms. A study showed that climacteric symptoms appear less frequently $(p<0.01)$ in women who practice physical exercise. ${ }^{17}$

Another population-based study, conducted in Natal, state of Rio Grande do Norte, with 365 women aged between 35 and 65 years also found a lower percentage of intense climacteric symptoms $(8.0 \%)$ in physically active women. ${ }^{18} \mathrm{~A}$ case control study showed that $63.6 \%$ of sedentary women had moderate to intense climacteric symptoms and better scores of quality of life were found among women who practiced physical exercise on a regular basis. ${ }^{19}$ That is why the climacteric period deserves special attention, as advice on healthy life habits (physical activity on a regular basis and adequate diet) may result in a significant decrease in the intensity of symptoms, thus providing women with a better quality of life.

From a psychological point of view, when experiencing climacteric, women have to deal with internal alterations resulting from hormonal changes, as well as with the loss of their reproductive potential and aging. Socially speaking, it is also possible to observe social issues during this period, such as children leaving home, illnesses, loss of loved ones, and sometimes stress and misunderstandings in the marital relationship. ${ }^{20}$ These changes may affect women's well-being and self-esteem to a great extent, making them vulnerable to the emergence of climacteric and to changes in sexuality.

Climacteric has transient and permanent symptoms and its incidence varies greatly, since it is directly influenced by factors related to the environment and each woman's singularities.

As for sexual performance, an association between the standard of sexual performance (SQF) and the intensity of symptoms (BKMI) was observed. Therefore, a high standard of sexual performance may be associated with low intensity climacteric symptoms.

A qualitative study on reasons that favored changes in sexual intercourse during climacteric, conducted in a health center of Jequié, state of Bahia, with 16 women aged between 45 and 59 years, showed that symptoms such as headache, nausea, hot flashes, menorrhagia, physiological changes in sexual intercourse, lack of sexual desire, decrease of pleasure and psychological changes affect sexual life and may interfere in women's sexual response. However, the same study found that some women had no changes at all in the quality of their sexual activities, both because of the absence of symptoms and the fact that they felt more comfortable with their sexuality, as a result of the cessation of the menstrual cycle and the possibility of pregnancy. ${ }^{21}$

These findings allude to studies that assess the complexity of sexual performance going beyond organic alterations, as it is the case for climacteric, since it is known that sexuality includes more than just physiological processes triggered by genital stimuli and is something more complex that involves different factors of emotional and affective nature, good communication with the partner, fantasies and sensory stimuli, which all contribute to awaken desire, pleasure and sexual satisfaction.

Therefore, the standard of sexual performance can also be reduced in climacteric women, 
as a result of the presence of psychological disorders (depression, anxiety), altered mood (irritability, nervousness), the use of medicine that inhibit the libido (antidepressants) and the quality of the relationship with the partner. ${ }^{22}$

It is important to highlight that, based on the mean age of the women who participated in this study (51 years), we observed that they were close to the transition period to menopause (as it occurs around the age of 50) and other studies have reported a decrease in the standards of sexual performance/satisfaction of women as age advances. ${ }^{1,23}$

The results presented in our study allow to raise the hypothesis that physical exercise can be associated with a lower intensity of climacteric symptoms and higher standards of sexual performance, ranging from fair to good/excellent. Thus, recommending the practice of physical exercise on a regular basis has been an efficient strategy in the prevention and reduction of climacteric symptoms. ${ }^{24}$

A very important factor to be mentioned is hypoestrogenism in climacteric, a condition in which vaginal lubrication makes sexual arousal response longer and less intense, thus being a determining factor for dyspareunia, which has altered orgasmic response as a consequence. This explains the fact that, when women begin to practice physical exercise, their bodies develop a greater ability to contract the musculoskeletal system, improving muscle flexibility and tone, oxygenating the pelvic organs responsible for vaginal lubrication, and contributing to better sexual performance and satisfaction. ${ }^{1}$

Women's sexuality in climacteric is still the object of preconceived ideas and taboos, and society has believed that women who are not in the reproductive period are asexual or incapable of practicing their sexuality. ${ }^{1}$ In this study, we observed that most women are sexually active.

Considering that the biological and psychosocial aspects of women's lives have a great effect on climacteric, the more information is given on symptoms, the easier it is to face this stage positively. ${ }^{1}$

It is imperative that climacteric women be treated adequately by trained health professionals in order to meet the needs of this group of people and advise women on changes that occur at this stage of their lives. ${ }^{25}$ In addition, among the different forms of action of nurses, the educating practice has been emerging as the main strategy for health promotion..$^{25-27}$

\section{CONCLUSION}

Climacteric symptoms classified as mild were associated with a higher standard of sexual performance considered as good/excellent, as we assumed that changes in the standard of sexual performance of climacteric women have a strong relationship with the intensity of these symptoms.

These findings suggest that the intensity of climacteric symptoms may affect sexuality, sexual response or the standard of sexual performance during that period. Moreover, this study also raises the hypothesis that practicing physical exercise may be associated with a lower intensity of climacteric symptoms and better sexual performance.

It is recommended that planning of health care services provided to climacteric women include health promotion by encouraging the practice of physical exercise on a regular basis.

\section{REFERENCES}

1. Ministério da Saúde (BR). Secretaria de Atenção à Saúde. Departamento de Ações Programáticas Estratégicas. Manual de atenção à mulher no climatério/menopausa. Brasília (DF): MS; 2008.

2. Fernandes ALRV, Pinto-Neto AM, Osis MJ, Conde DM, Sousa MH, Costa-Paiva L. Sexuality in Brasilian women age 40 to 65 years or more of formal education: associated factors. Menopause. 2008; 15(2):264-9.

3. Serrão C. (Re)pensar o climatério feminino. Aná Psicológica [online]. 2008 [acesso 2013 Ago 12]; 26(1):15-23. Disponível em: http://www.scielo. gpeari.mctes.pt/pdf/aps/v26n1/v26n1a02.pdf

4. Pereira $\mathrm{Q}$, Silva $\mathrm{C}$, Siqueira H. Processo de viver de mulheres climatérias usuárias do Sistema Único de Saúde. Ciênc Cuid Saúde [online]. 2008 [acesso 2013 Ago 10];7(2):224-31. Disponível em: http://www.periodicos.uem.br/ojs/index.php/ CiencCuidSaude/article/view/5006/3245

5. Ministério da Saúde (BR). Secretaria de Atenção à Saúde. Departamento de Ações Programáticas Estratégicas. Política nacional de atenção integral à saúde da mulher: princípios e diretrizes. Brasília (DF): MS; 2009. 
6. Berni NIO, Luz MH, Kohlrausch SC. Conhecimento, percepções e assistência à saúde da mulher no climatério. Rev Bras Enferm [online]. 2007 [acesso 2013 Set 23]; 60(3):299-306. Disponível em: http:// www.scielo.br/pdf/reben/v60n3/a10.pdf

7. Rampanele A. A prática de atividade física entre mulheres frequentadoras de academia no climatério e menopausa [monografia]. Novo Hamburgo (RS): Universidade Feevale; 2010.

8. Silva Filho EA, Costa AM. Avaliação da qualidade de vida de mulheres no climatério atendidas em hospital-escola na cidade do Recife, Brasil. Rev Bras Ginecol Obstet [online]. 2008 [acesso 2013 Ago 12]; 30(3):113-20. Disponível em: http:/ / www.scielo.br/ pdf/rbgo/v30n3/3099.pdf

9. Maron L, Leal A, Bandeira D, Macedo PS, Garcia SS, Silva EB. A assistência às mulheres no climatério: um estudo bibliográfico. Rev Contexto Saúde [online]. 2011 [acesso 2014 Out 27]; 10(20):545-50. Disponível em: https://www.revistas.unijui.edu.br/index. php/contextoesaude/article/view/1576/1331

10. Hallal PC, Carvalho YM, Tassitan RM, Tenório MCM, Warschauer M, Reis RS, et al. Avaliação quali-quantitativa do programa academia da cidade, Recife (PE): concepções dos professores. Rev Bras Ativ Fís Saúde [online]. 2009 [acesso 2013 Ago 6];4(1):9-13. Disponível em: http:/ / www.sbafs.org. br/_artigos/87.pdf

11. Abdo CHN. Quociente sexual feminino: um questionário brasileiro para avaliar a atividade sexual da mulher. Diagn Tratamento [online]. 2009 [acesso 2013 Set 10]; 14(2):89-1. Disponível em: http:/ / files.bvs.br/upload/S/1413-9979/2009/ v14n2/a0013.pdf

12. De Lorenzi DRS, Catan LB, Moreira K, Ártico GR. Assistência à mulher climatérica: novos paradigmas. Rev Bras Enferm [online]. 2009 [acesso 2013 Set 10]; 62(2):287-93. Disponível em: http:/ / www.scielo.br/ pdf/reben/v62n2/a19v62n2.pdf

13. Sousa RL, Sousa ESS, Silva JCB, Filizola RG. Fidedignidade do Teste-reteste na aplicação do Índice Menopausal de Blatt e Kupperman. Rev Bras Ginecol Obstet [online]. 2000 [acesso 2013 Set 08]; 22(8):481-7. Disponível em: http:/ / www.scielo.br/ pdf/rbgo/v22n8/12063

14. Díaz-Yamal I, Munévar-Veja L. Fitoestrógenos: revisión de tema. Rev Colomb Obstet Ginecol [online]. 2009 [acesso 2013 Set 08]; 60(3):27480. Disponível em: http://www.fecolsog.org/ userfiles/file/revista/Revista_Vol60No3_Julio_ Septiembre_2009/v60n3a08.pdf

15. Abdo CHN. Elaboração e validação do quociente sexual - versão feminina: uma escala para avaliar a função sexual da mulher. Rev Bras Med [online]. 2006 [acesso 2013 Set 18];63(9):477-82. Disponível em: http://www.moreirajr.com.br/revistas. asp?fase $=$ r003\&id_materia $=3404$

16. Ministério da Saúde (BR). Conselho Nacional de Saúde. Resolução 196, de 10 de outubro 1996: diretrizes e normas regulamentadoras de pesquisas envolvendo seres humanos. Brasília (DF); 1996.

17. Gonçalves AKS, Canário ACG, Cabral PUL, Silva RAH, Spyrides MHC, Giraldo PC, et al. Impacto da atividade física na qualidade de vida de mulheres de meia idade: estudo de base populacional. Rev Bras Ginecol Obstet [online]. 2011 [acesso 2014 Out 27]; 33(12):408-13. Disponível em: http://www.scielo. br/pdf/rbgo/v33n12/v33n12a06.pdf

18. Canario ACG. Avaliação dos efeitos da atividade física sobre a qualidade de vida de mulheres de meia idade: estudo de base populacional [dissertação]. Natal (RN): Universidade Federal do Rio Grande do Norte, Programa Pós-Graduação em Ciências da Saúde; 2011.

19. Tairova OS, De Lorenzi DRS. Influência do exercício físico na qualidade de vida de mulheres na pósmenopausa: um estudo caso-controle. Rev Bras Geriatr Gerontol [online]. 2011 [acesso 2013 Ago 16]; 14(1):135-45. Disponível em: http:/ / www.scielo.br/ pdf/rbgg/v14n1/a14v14n1.pdf

20. Silva AR, Ferreira TF, Tanaka ACD. História ginecológica e sintomatologia climatérica de mulheres pertencentes a uma unidade de saúde pública do Estado do Acre. Rev Bras Crescimento Desenvolv Hum [online]. 2010 [acesso 2013 Set 18]; 20(3):778-86. Disponível em: http:/ / www.journals. usp.br/jhgd/article/download/19986/22072

21. Aderne FO, Araújo RT. Influência da menopausa no padrão sexual: opinião de mulheres. Rev Saúde Com [online]. 2007 [acesso 2013 Out 05]; 3(2):48-60. Disponível em: http://www.uesb.br/revista/rsc/ v3/v3n2a06.pdf

22. Dennerstein L. Sexuality, midlife, and menopause. Menopause. 2008; 15(2):221-2.

23. Basson R. Sexual desire and arousal disorders in women. N Engl J Med. 2006; 354(4):1497-506.

24. Zanesco A, Antunes E. Effects of exercise training on the cardiovascular system: pharmacological approaches. Pharmacol Ther. 2007; 114(3):307-17.

25. Silva LD, Beck CLC, Dissen CM, Tavares JP, Budó MLD, Silva HS. O enfermeiro e a educação em saúde: um estudo bibliográfico. Rev Enferm UFSM [online]. 2012 Mai-Ago [acesso 2013 Set 10];2(2):412-9. Disponível em: http:/ / cascavel.ufsm. $\mathrm{br} /$ revistas/ojs-2.2.2/index.php/reufsm/article/ view/2676/3769 
26. Souza LM, Wegner W, Gorini MIPC. Educação em saúde: uma estratégia de cuidado ao cuidador leigo. Rev Latino-am Enferm [online]. 2007 [acesso 2013 Dez 04]; 15(2):337-43. Disponível em: http:/ / www. scielo.br/pdf/rlae/v15n2/pt_v15n2a22.pdf
27. Rigon AG, Neves ET. Educação em saúde e a atuação de enfermagem no contexto de unidades de internação hospitalares o que tem sido ou há para ser dito? Texto Contexto Enferm [online]. 2011 [acesso 2014 Mar 24]; 20(4):812-7. Disponível em: http:// www.scielo.br/pdf/tce/v20n4/22.pdf
Correspondence: Estela Rodrigues Paiva Alves

Rua Edvaldo Bezerra Cavalcanti Pinho, 320, ap. 203 58045-270 - Cabo Branco. João Pessoa, PB, Brasil

E-mail: rodrigues.estela@gmail.com
Received: February 26, 2014

Approved: October 02,2014 